\title{
PENGARUH TEKNOLOGI INFORMASI TERHADAP KINERJA INDIVIDUAL: COMPUTER ANXIETY SEBAGAI VARIABEL MODERATING (STUDI PADA BPR KOTA LAMPUNG)
}

\author{
Lego Waspodo \\ Universitas Negeri Lampung \\ e-mail: legowaspodo@yahoo.com
}

\begin{abstract}
ABSTRACK
This research is based on the importance of information system technology to the individuals performance, which is moderated with Computer Anxiety. It was used the population Manager of Bank Perkreditan Rakyat (BPR) in Lampung. The influence of nformation system technology to the individuals performance was analyzed by using original least square regression, and the influence of the moderated variable (Computer Anxiety) to officers performance were analyzed by using Moderated Regression Analysis (MRA). The result receives both of the hypothesis.
\end{abstract}

Keywords: information system technology, individuals performance, Computer Anxiety

\section{PENDAHULUAN}

Perkembangan teknologi informasi pada dunia industri berkembang semakin pesat pada dekade terakhir. salah satu industri yang mengalami transformasi dalam implementasi teknologi informasi adalah industri perbankan. Tekanan persaingan dan tuntutan kualitas layanan bagi nasabah, serta aktivitas operasi bank yang kompleks, akibat jenis transaksi yang beragam, mendorong bank melakukan otomatisasi operasionalnya dengan implementasi teknologi informasi (Meiranto, 2011). Penggunaan teknologi informasi (TI) sebagai alat ukur untuk mengevaluasi kinerja telah mengundang serangkaian perdebatan yang kemudian mendorong para peneliti untuk melakukan penelitian di bidang ini. Penelitian ini menguji variabel kontijensi sebagai variabel moderating yaitu Computer Anxiety dengan teknologi informasi (TI) dalam mempengaruhi kinerja individual.
Anxiety merupakan suatu persepsi mengenai kesukaran, kesulitan berpikir yang disebabkan oleh ketakutan pada sesuatu yang akan terjadi (Macquire Dictionary, 2013). Sedangkan menurut May dalam Yunita (2004), anxiety adalah sebagai suatu ketakutan pada sesuatu yang akan terjadi atas adanya ancaman terhadap beberapa nilai yang dianggap penting oleh individu atas keberadaannya sebagai orang pribadi. Computer Anxiety merupakan sebagai suatu kecenderungan seseorang menjadi susah, khawatir, atau ketakutan mengenai penggunaaan teknologi informasi (komputer) pada masa sekarang atau yang akan datang (Igbarian, 1989).

Teknologi informasi merupakan sesuatu yang dibutuhkan oleh pelaku bisnis dalam menjalankan fungsi manajemen dalam menentukan langkah strategis untuk mencapai tujuan. Seyogyanya implementasi teknologi informasi mampu meningkatkan kinerja individual seseorang. 


\section{REVIEW LITERATUR DAN HIPOTESIS}

\section{Pengaruh Teknologi Informasi terhadap kinerja}

Teknologi informasi merupakan sumber daya berwujud yang dimiliki oleh perusahaan (Hitt et al, 2001) dan merupakan sumber daya organisasi strategik (Wade \& Hulland dalam Tanriverdi, 2006). Selain itu juga Aji (2005), menjelaskan bahwa teknologi informasi adalah teknologi yang memanfaatkan komputer sebagai perangkat utama untuk mengolah data menjadi informasi yang bermanfaat. Kinerja merupakan hasil kerja yang dicapai oleh seseorang atau kelompok orang dalam organisasi, sesuai dengan wewenang dan tanggung jawab masing-masing (Effendi, 2001).

Penelitian mengenai implementasi sebuah sistem teknologi yang berdampak terhadap kinerja pegawai sudah banyak dilakukan sebelumnya. Pramuka dkk (2010) menemukan bahwa sistem informasi berpengaruh positif terhadap kinerja Pegawai. Primasari (2013) menemukan bahwa implementasi sistem pengukuran kinerja berpengaruh positif terhadap kinerja manajerial, Arbenethy (2005) menemukan bahwa Management Accounting System berpengaruh positif terhadap kinerja manajer perusahaan manufaktur di Australia. Adanya implementasi teknologi informasi seyogyanya akan membantu secara positif para pegawai dalam melakukan aktivitas operasionalnya sehari-hari. Teknologi informasi yang dalam hal ini adalah penggunaan komputer diasumsikan memberikan pegaruh positif terhadap kinerja invidual. Berdasarkan uraian di atas dan riset-riset sebelumnya, maka hipotesis pertama adalah sebagai berikut.

H1 : Teknologi informasi berpengaruh positif terhadap kinerja individual.

\section{Computer Anxiety memoderasi Pengaruh Teknologi Informasi terhadap Kinerja Individual}

Implementasi Teknologi Informasi tidak akan sukses jika tidak dibarengi dengan perilaku individu (pegawai) yang mendukung implementasi sistem tersebut. Menurut Orr dalam Handoyo (2012) Computer Anxiety merupakan salah satu technophobia yang mana komputer merupakan salah satu teknologi yang berkembang dalam kehidupan manusia yang dapat menimbulkan sikap pobia bagi orang yang akan menggunakannya.

Penelitian Igbaria dan Tan (1989), Webster (1990) serta Indriantoro (2000) menemukan bahwa kecendrungan seseorang menjadi susah, khawatir atau ketakutan terhadap komputer di masa sekarang dan di masa yang akan datang mempunyai pengaruh negatif terhadap sikap pemakai dengan teknologi informasi khususnya komputer.

Logikanya implementasi Teknologi Informasi terhadap kinerja tidak akan efektif bila dipengaruhi oleh faktor Computer Anxiety. Mengacu pada penelitian Igbaria dan Tan (1989), Webster (1990) dan Indriantoro (2000) yang membuktikan bahwa Computer Anxiety secara langsung berpengaruh negatif terhadap kinerja, maka dirumuskan hipotesis sebagai berikut.

$\mathrm{H} 2$ : Computer Anxiety memoderasi secara negatif pengaruh implementasi Teknologi Informasi terhadap kinerja Individual.

\section{Gambar 1 \\ Model Penelitian}

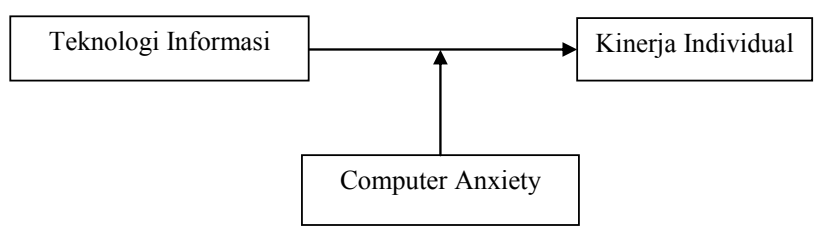




\section{METODE PENELITIAN}

\section{Jenis Penelitian}

Jenis penelitian yang digunakan dalam penelitian ini adalah penelitian pengujian hipotesis (hypotheses testing) yaitu penelitian yang menjelaskan fenomena dalam bentuk hubungan antar variabel. Tipe hubungan antar variabel dalam penelitian ini adalah hubungan sebab akibat atau sering disebut dengan hubungan kausalitas.

Jenis data yang digunakan adalah data subyek yaitu data penelitian yang berupa opini, sikap, pengalaman atau karakteristik dari seseorang atau sekelompok orang yang menjadi subyek penelitian (Indriantoro dan Supomo, 1999). Sumber data yang dipergunakan dalam penelitian adalah data primer dalam bentuk persepsi responden (subyek) penelitian dan instrumen yang digunakan adalah kuesioner atau angket.

\section{Populasi dan Sampel}

Populasi dalam penelitian ini adalah para manajer yang bekerja pada Bank Perkreditan Rakyat (BPR) di Kota Lampung. Adapun sampel yang digunakan adalah manajer keuangan, manajer personalia, manajer administrasi, teknologi informasi, dan manajer pemasaran. Penggunaan manajer sebagai sampel dalam penelitian ini karena pertama, BPR manajer bank memiliki persepsi yang berbeda computer anxiety) dan kinerja, kedua manajer yang memimpin divisi dalam organisasi juga bertindak sebagai pimpinan divisi yang diberi wewenang dan tanggung jawab terhadap kebijakan pengaturan bisnis dan informasi perusahaan. Teknik pengumpulan data atau pola pengambilan sampel pada penelitian adalah dengan menggunakan metode sensus Sampling.

\section{Uji Hipotesis}

Analisis statistik yang digunakan adalah analisis regresi sederhana dan berganda sebagai model yang memprediksi hubungan kausal antara variabel dependen dengan beberapa variabel independen. Regresi linear sederhana untuk menguji hubungan antara teknologi sistem informasi dengan kinerja individual dan menguji hubungan variabel moderating computer anxiety dengan kinerja individual. Moderated regression analysis $(M R A)$ digunakan untuk menentukan hubungan interaksi antara variabel dependen dan independen oleh satu variabel sebagai variabel moderating (Nunnally, 1994). Persamaan statistika yang digunakan adalah sebagai berikut:

1. $K I=a+b_{1} T I+e$

2. $\mathrm{KI}=\mathrm{a}+\mathrm{b}_{1} \mathrm{TI}+\mathrm{b}_{2} \mathrm{CA}++\mathrm{e}$

$$
\begin{array}{ll}
\mathrm{KI} & =\text { Kinerja Individual } \\
\mathrm{TI} & =\text { Teknologi informasi } \\
\mathrm{CA} & =\text { Computer Anxiety } \\
\mathrm{a} & =\text { intercept } \\
\mathrm{e} & =\text { error }
\end{array}
$$

\section{HASIL PENELITIAN DAN PEMBAHASAN}

\section{Statistik Deskriptif}

Data yang diperoleh dalam penelitian ini dikumpulkan dengan menyebarkan kuesioner kepada responden pada para manajer di Kota Lampung total kuesioner yang dikirim sebanyak 50 kuesioner kepada para manajer yang meliputi manajer keuangan, manajer personalia, manajer administrasi, teknologi informasi, dan manajer pemasaran.

Secara lengkap data akan disajikan dalam tabel 1 berikut ini: 
Tabel 1

Rincian Pengiriman Pengembalian

Kuesioner

\begin{tabular}{lc}
\hline \multicolumn{1}{c}{ Keterangan } & Jumlah Kuesioner \\
\hline - Kuesioner yang didistribusikan & 50 kuesioner \\
- Kuesioner yang diterima (kembali) & 50 kuesioner \\
- Kuesioner yang tidak kembali & 0 kuesioner \\
- Kuesioner yang gugur (tidak & \\
$\begin{array}{l}\text { lengkap pengisiannya) sehingga } \\
\text { tidak dapat diolah }\end{array}$ & 2 kuesioner \\
- Kuesioner yang lengkap & 48 kuesioner \\
- Tingkat pengembalian (respon rate) & $(50 / 50 * 100 \%=100 \%$ \\
- Tingkat pengembalian yang bisa & $(48 / 50) * 100 \%=96 \%$ \\
\hline
\end{tabular}

Sumber : Data diolah, 2013

\section{Gambaran Umum Responden}

Karakteristik dari 48 responden yang diobservasi akan digambarkan dalam bentuk tabel supaya lebih mudah dipahami. Gambaran umum mengenai responden ini sajikan untuk melihat profil serta karakteristik dari data penelitian tersebut dan hubungan yang ada antar variabel yang digunakan dalam penelitian tersebut. Karakteristik responden berdasarkan jenis kelamin, pendidikan, jabatan dan lama bekeja akan disajikan dalam tabel 2 berikut:

\section{Tabel 2}

Profil Responden

\begin{tabular}{lcc}
\hline \multicolumn{1}{c}{ Keterangan } & $\begin{array}{c}\text { Jumlah } \\
\text { (Orang) }\end{array}$ & Persentase (\%) \\
\hline Jenis Kelamin & & \\
$\quad$ Pria & 33 & $68,75 \%$ \\
$\quad$ Wanita & 15 & $31,25 \%$ \\
Pendidikan & & \\
D3 & 8 & 16,67 \\
S1 & 32 & $66,67 \%$ \\
S2 & 8 & $16,67 \%$ \\
Lama bekerja & & \\
Dibawah 3 tahun & 9 & $18,75 \%$ \\
Diatas 3 tahun & 39 & $81,25 \%$ \\
\hline
\end{tabular}

Sumber : Data diolah, 2013

\section{Uji Validitas dan Reliabilitas}

Uji kualitas data meliputi realibilitas dan uji validitas. Uji reliabitas dilakukan dengan uji cronbach alpha menggunakan SPSS. Suatu konstruk dikatakan reliabel jika memberikan nilai cronbach alpha $>0,60$ (Nunnaly dalam Imam, 2005). Berikut ini adalah rekapitulasi hasil uji reliabilitas yang disajikan pada tabel 3 .

\section{Tabel 3}

Hasil Uji Reliabilitas

\begin{tabular}{clcc}
\hline No & Variabel & Nilai Cronbach Alpha & Keterangan \\
\hline 1 & Teknologi Informasi & 0.723 & Reliabel \\
2 & Kinerja Individual & 0.870 & Reliabel \\
3 & Computer Anxiety & 0.918 & Reliabel \\
\hline
\end{tabular}

Sumber: Data diolah, 2013

\section{Tabel 4}

\section{Hasil Uji Validitas}

\begin{tabular}{|c|c|c|c|c|}
\hline No & Variabel & $\begin{array}{l}\text { Kisaran } \\
\text { Korelasi }\end{array}$ & Signifikansi & Keterangan \\
\hline 1 & $\begin{array}{l}\text { Teknologi } \\
\text { Informasi }\end{array}$ & $\begin{array}{c}0.765 * * \\
0.829 * *\end{array}$ & 0.01 & Valid \\
\hline 2 & $\begin{array}{l}\text { Kinerja } \\
\text { Individual }\end{array}$ & $\begin{array}{c}0.741 * * \\
0.888 * *\end{array}$ & 0.01 & Valid \\
\hline 3 & $\begin{array}{l}\text { Computer } \\
\text { Anxiety }\end{array}$ & $\begin{array}{c}0.748 * * \\
0.832 * *\end{array}$ & 0.01 & Valid \\
\hline
\end{tabular}

Sumber: Data diolah, 2013

\section{Uji Normalitas}

\section{Gambar 2 \\ Histogram}

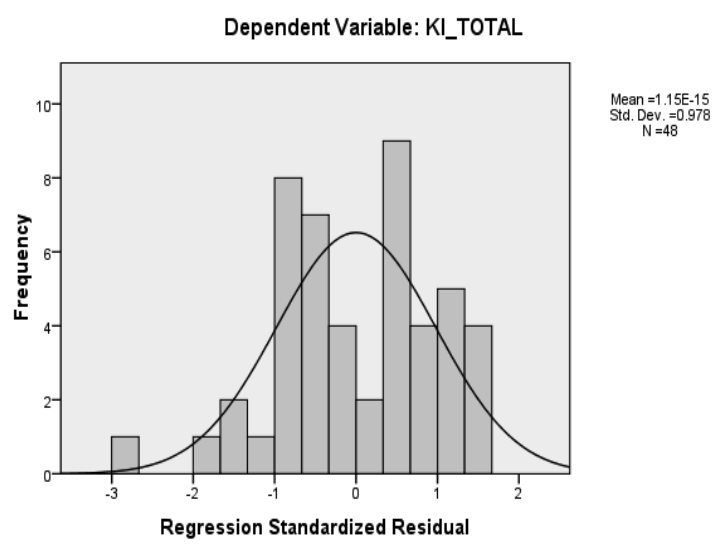




\section{Gambar 3 \\ Normal P-P Plot of Regression Standardized Residual}

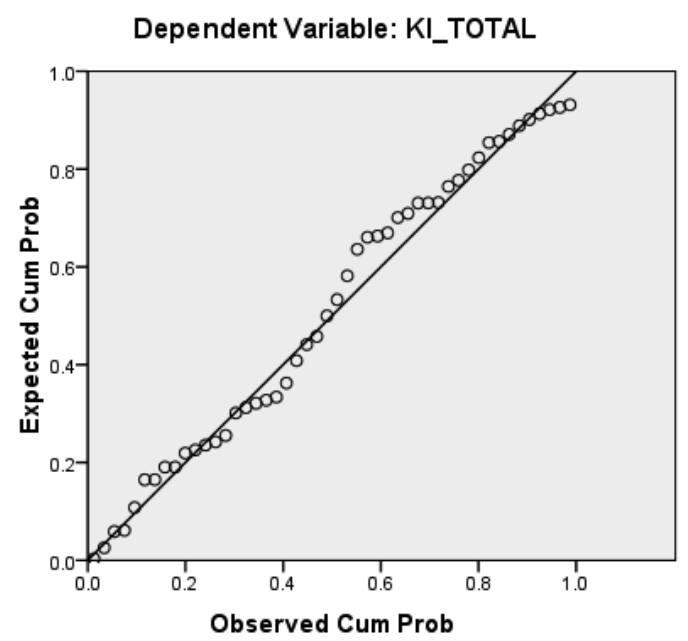

Dari hasil output dapat dilihat bahwa data menyebar di sekitar garis diagonal dan mengikuti arah garis diagonal atau grafik histogramnya menunjukkan pola distribnusi normal, maka model regresi memenuhi asumsi normalitas.

\section{Uji Multikolinieritas}

Dari hasil uji Variance Inflation Factor (VIF) dengan bantuan software SPSS for Windows, diketahui nilai VIF variabel teknologi informasi sebesar 1,105 dan nilai VIF variabel ketidakpastian tugas sebesar 1,105, masing-masing lebih kecil dari 5, sehingga dapat disimpulkan tidak ada multikolinearitas di antara variabel bebas dalam model regresi.

\section{Uji Autokorelasi}

Berdasarkan hasil perhitungan menunjukkan bahwa nilai Durbin Watson (DW) sebesar 1,031 , nilai ini dibandingkan dengan nilai tabel menggunakan nilai signifikansi 0,01, jumlah sampel 48 dan jumlah variabel independen 2 $(\mathrm{k}=2)$ maka diperoleh nilai $\mathrm{d}_{\mathrm{L}}$ sebesar 1,285 dan
$\mathrm{d}_{\mathrm{U}}$ sebesar 1,446. Jadi dapat dikatakan bahwa DW 1,031 lebih kecil dari batas atas $\left(\mathrm{d}_{\mathrm{U}}\right)$ 1,446 dan kurang dari 4-1,446 (4- $\left.\mathrm{d}_{\mathrm{v}}\right)$, sehingga dapat diartikan bahwa terdapat autokorelasi positif. Autokorelasi muncul karena observasi yang berurutan sepanjang waktu.

\section{Uji Heteroskedastisitas}

Deteksi ada atau tidaknya heterokedastisitas dilakukan dengan melihat ada atau tidaknya pola tertentu (bergelombang, melebar kemudian menyem kemudian menyempit) pada grafik plot (scatterplot) antara nilai prediksi variabel terkait dengan residualnya.

\section{Gambar 4 \\ Scatterplot}

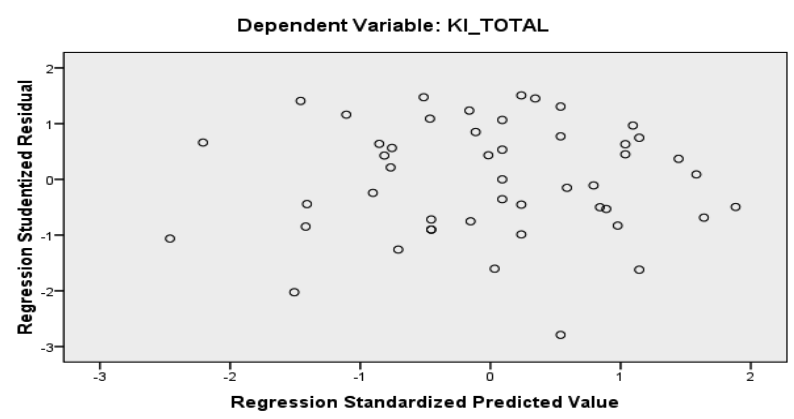

dari grafik scatterplots terlihat bahwa titik-titik menyebar secara acak serta tersebar baik di atas maupun di bawah angka 0 pada sumbu Y. Hal ini dapat disimpulkan bahwa tidak terjadi heteroskedesitas pad amodel regresi, sehingga model regresi layak untuk digunakan

\section{Uji Hipotesis}

\section{Tabel 5}

\begin{tabular}{lccccccc}
\multicolumn{5}{c}{ Ringkasan Hasil Pengujian Hipotesis 1 } \\
\hline $\begin{array}{c}\text { Adjusted } \\
\text { R Square }\end{array}$ & & & & & & Keterangan \\
\hline Hipotesis & & F & Sig & t & Sig & \\
H1 & & & & & & \\
TI - KI & 0,282 & - & - & 4.4415 & 0,000 & Berpengaruh \\
\hline
\end{tabular}


Tabel 6

Ringkasan Hasil Pengujian Hipotesis 2

\begin{tabular}{|c|c|c|c|c|c|c|}
\hline & Adjusted & & & & & \\
\hline Hipotesis & R Square & & & & & Keterangan \\
\hline & & B & Std. Error & $\mathrm{t}$ & Sig & \\
\hline $\mathrm{H} 2$ & 0,276 & & & & & \\
\hline TI & & 0,692 & .581 & 3.058 & .000 & Berpengaruh \\
\hline INTERAKSI & & -.016 & .021 & -7.75 & .044 & Berpengaruh \\
\hline
\end{tabular}

Teknologi Informasi Berpengaruh Terhadap Kinerja Individual $\left(\mathrm{H}_{1}\right)$

Pengujian hipotesis 1 dilakukan dengan melihat interaksi antara variabel Teknologi Informasi dengan Kinerja Individual (persamaan 1), menunjukkan besarnya adjusted $\mathrm{R}^{2}$ adalah 0,282 , hal ini berarti $28,2 \%$ variasi kinerja ndividual dapat dijelaskan oleh variasi dari variabel teknologi informasi, sedangkan sisanya dijelaskan oleh sebab-sebab yang lain di luar model. Dari model regresi tampak pengaruh variabel Teknologi Informasi signifikan pada $\alpha 0,05$, hal ini berarti bahwa variabel Kinerja ndividualdipengaruhi oleh Teknologi Informasi.

Teknologi informasi terbukti berpengaruh terhadap kinerja Individual. Hal tersebut mengindikasikan bahwa dengan pengelolaan sumber daya teknologi informasi yang dilakukan oleh organisasi dalam hal ini infrastruktur, strategi, sumber daya manusia akan meningkatkan pemahaman perusahaan/ organisasi terhadap job description dan kegiatan operasional organisasi sehari-hari, sehingga dengan adanya pemahaman tersebut, perusahaan mampu meningkatkan kinerja Individual. Hasil ini juga mendukung penelitian-penelitian sebelumnya Bambang Agus Pramuka,dkk (2010) ,Primasari, (2013), Arbenethy (2005). Adanya implementasi teknologi informasi seyogyanya akan membantu secara positif para pegawai dalam melakukan aktivitas operasionalnya sehari-hari.

\section{Computer Anxiety memoderasi Pengaruh Teknologi Informasi terhadap Kinerja Individual}

Hasil pengujian hipotesis 2 dapat dilihat menunjukkan besarnya adjusted $\mathrm{R}^{2}$ adalah 0,276 , hal ini berarti $27,6 \%$ variasi Kinerja Individual dapat dijelaskan oleh variasi variabel independen Teknologi Informasi, Computer Anxiety, dan Interaksi, sedangkan sisanya dijelaskan oleh sebab-sebab lain di luar model. Dari uji statistik $\mathrm{F}$ hitung diperoleh sebesar 9,963 pada $\alpha 0,05$, sehingga model regresi dapat digunakan untuk memprediksi Kinerja Individual atau dapat dikatakan bahwa Teknologi Informasi, Computer Anxiety, dan Interakssecara bersama-sama berpengaruh terhadap Kinerja Individual. Hasil output SPSS terlihat jelas bahwa variabel interaksi memberikan koefisien -0.16 dan signifikan pada 0.44 yang berarti variabel Computer Anxiety adalah pure moderator atau variabel moderating.

Implementasi Sistem tidak akan sukses jika tidak dibarengi dengan perilaku individu (pegawai) yang mendukung implementasi sistem tersebut Jaworski dan Young (1992: 18). Computer Anxiety merupakan sebagai suatu kecenderungan seseorang menjadi susah, khawatir, atau ketakutan mengenai penggunaaan teknologi informasi (komputer) pada masa sekarang atau yang akan datang (Igbarian,1989). Adanya sikap tersebut secara langsung akan mempengaruhi secara negatif implementasi teknologi informasi terhadap kinerja individual. Semakin tinggi tingkat Computer Anxiety seseorang akan mengakibatkan semakin rendah kinerja seseorang. Logika nya implementasi suatu sistem terhadap kinerja tidak akan efektif bila dipengaruhi oleh faktor Computer Anxiety. Berdasarkan hasil penelitian diketahui Computer Anxiety adalah pure moderator atau variabel moderating. Computer Anxiety memoderasi secara negatif pengaruh implementasi teknologi informasi terhadap kinerja individual. 


\section{KESIMPULAN DAN SARAN}

\section{Kesimpulan}

Penelitian ini memberikan indikasi pentingnya teknologi informasi dalam melakukan fungsi-fungsi manajemen dan menilai prestasi seseorang. Hasil penelitian ini mempertegas dan mendukung temuan Hirst (1981) yang menjelaskan bahwa teknologi informasi dapat digunakan oleh manajemen untuk proses perencanaan, koordinasi dan penilaian evaluasi yang nantinya dijadikan pedoman di masa mendatang. Penggunaan teknologi informasi dapat berdampak positif terhadap bawahan dan teknologi informasi baik sebagai penilaian prestasi seseorang. Hasil penelitian ini juga mempertegas terdapat pengaruh simultan yang signifikan antara Computer Anxiety, dan teknologi informasi terhadap kinerja individual sehingga variabel yang diajukan sebagai variabel moderating memoderasi pengaruh teknologi informasi terhadap kinerja individual seperti yang dihipotesiskan.

\section{Saran}

Berdasarkan keterbatasan tersebut, maka dikemukakan beberapa dalam penelitian selanjutnya sebagai berikut:

1. Perlu dilakukan pengembangan instrumen yaitu disesuaikan dengan kondisi dan lingkungan dari objek yang diteliti.

2. Penelitian mendatang dapat mempertimbangkan sumber daya lainnya yang dimiliki oleh organisasi yang dapat meningkatkan kinerja pegawai

3. Penelitian selanjutnya dapat menggunakan variabel kontijensi yang diajukan tidak sebagai variabel moderating karena beberapa peneliti menyatakan bahwa variabel tersebut berpengaruh langsung terhadap kinerja. Selain itu pula dapat digunakan variabel kontijensi yang lain, seperti desentralisasi dan komitmen.
4. Penggunaan self rating pada pengukuran kinerja pegawai dapat diperbaiki dengan mengacu pada penelitan-penelitan yang sudah dilakukan sebelumnya, dengan melibatkan responden pihak lain untuk menilai kinerja rekannya.

\section{DAFTAR PUSTAKA}

Arbenethy, Jan Bouwens.2005. "Determinantof accounting Innovation". ABASCUS

Aji Supriyanto. 2005. "Pengantar Teknologi Informasi”. Edisi Pertama. Penerbit Salemba Empat. Jakarta

Bambang Agus Pramuka, Dona Prinasari, Widyahayu. 2010.'Pengaruh Sistem Informasi Akuntansi terhadap Kinerja manajerial”. Jurnal JEBA FE UNSOED. Purwokerto

David Eendi, 2001, "Pengaruh Informasi Akuntansi Terhadap Kinerja Manajer Dengan Ketidakpastian Tugas Sebagai Variabel Moderating", Tesis Magister Sains Akuntansi Undip Semarang (Tidak Dipublikasikan)

Hirst, Mark K, 1981, "Accounting Information And The Evaluation Of Subordinate Performance: A Situational Approach”, The Accounting Review Vol. LVI, No. 4, Oktober pp.771-784

Indriantoro, Nur. 1996. “ Sistem Infomasi Strategik Dampak Teknologi Informasi terhadap organisasi dan keunggulan kompetitif'. Jurnal KOMPAK, No.9.

Meiranto, Wahyu. 2011. “ Kajian Online Sistem Informasi BRI ((BRINETS) : Pendekatan Technology Acceptance Model'. Jurnal Akuntansi Mulitparadigma,vo.2.no.1.,F akultas Ekonomi dan Bisnis Universitas Brawijaya. Malang

Indriantoro, Nur. 2000. "Pengaruh computer anxiety terhadap keahlian dosen dalam 
penggunaan komputer". Jurnal Akuntansi dan Auditing Indonesia, Vol.4.

Imam Ghozali, 2005, Aplikasi Analisis Multivariate Dengan Program SPSS: Edisi Kedua Badan Penerbit Undip Semarang

Primasari, Dona. Sudjono, Widyahayu. 2013. "Sistem Pengukuran Kinerja dengan dua variabel intervening". Jurnal Bisnis dan Ekonomi Vo.11. No,1. FE Univ. Muhamadiyah Magelang

Yunita, Dian. 2004. "Pemgaruh tingkat computer anxiety terhadap keahlian dosen akuntansi dalam menggunakan komputer. Skripsi UNS Solo(Tidak Dipublikasikan). 